\title{
Dynamics of Changes in Composition and Stability of the Heavy Oil Sampled from the Usinskoye Oil Field as a Result of Formation Treatment with a Sol-Forming EOR System
}

\author{
Darya I. Chuikina*, \\ Tatiana V. Petrenko, Larisa D. Stakhina \\ Institute of Petroleum Chemistry SB RAS \\ 4 Akademichesky, Tomsk, 634055, Russia
}

Received 26.03.2019, received in revised form 19.09.2019, accepted 11.11.2019

\begin{abstract}
The paper deals with a sol-forming system for oil recovery enhancement (EOR system) used to increase the rate of heavy oil displacement. The effect of sol-forming EOR system during the heavy oil displacement on the composition and stability of oil sampled from the Usinskoye oil field of Russia is investigated. The composition of a crude oil also plays an important role in changing its stability. The work is aimed to investigate stability of heavy crude oil in regards to asphaltene precipitation. For asphaltene toluene/n-heptane solutions, the aggregation stability of asphaltenes based on change in the optical density with time is investigated via spectrophotometry. SARA analysis is used to characterize the compositions of heavy oils. First, the content of asphaltenes precipitated from the oil samples is determined and then the samples of deasphalted crude oil (maltenes) are analyzed by the method of liquid adsorption chromatography for the purpose to study the composition of oil sampled from the wells before and after their treatment with the sol-forming EOR system. It is found out that the treatment of reservoir crude oil with the sol-forming EOR system results in changes in composition of saturated, aromatic hydrocarbons, resins, and asphaltenes (SARA components) and aggregative stability of produced oil. The results obtained showed that the aggregative stability of heavy oil depends not only on the content of SARA components in the dispersion medium but on the presence of metalloporphyrins in the oil. Metalloporphyrins could act as inhibitors of asphaltene precipitation, which is an additional factor responsible for the stabilization of the oil dispersed system.
\end{abstract}

Keywords: EOR methods, sol-forming system, displacement, heavy crude oil, composition, asphaltenes, resins, hydrocarbons, metalloporphyrins, stability, spectrophotometry.

(C) Siberian Federal University. All rights reserved

* Corresponding author E-mail address: dichuikina@mail.ru 


\title{
Динамика изменения состава и устойчивости нефти Усинского месторождения в результате обработки
}

\author{
пласта золеобразующей композицией \\ для интенсификации нефтеотдачи
}

\author{
Д.И. Чуйкина, Т.В. Петренко, Л.Д. Стахина \\ Институт химии нефти СО РАН \\ Россия, 634055, Томск, пр. Академический, 4
}

\begin{abstract}
Чтобы улучшить интенсивность вытеснения тяжелой нефти, используют золеобразуюшую композицию для увеличения нефтеотдачи (EOR). Исследовано влияние золеобразуюшей композиции в качестве метода увеличения нефтеотдачи (EOR) при вытеснении тяжелой нефти на состав и устойчивость образиов из Усинского нефтяного месторождения России. Важное влияние на устойчивость нефти оказывает ее состав. Целью исследования является изучение устойчивости тяжелой нефти в отнотении осаждения асфальтенов. Агрегационная устойчивость асфальтенов была изучена на основе изменения оптической плотности во времени для растворов асфальтенов в толуоле/н-гептане методом спектрофотометрии, для характеристики состава тяжельх нефтей использовали анализ содержания насыщенных ароматических углеводородов, смол и асфальтенов. Состав образиов нефти из скважин до и после обработки золеобразующей композицией, используемой для увеличения нефтеотдачи, изучали методом жидкостно-адсорбиионной хроматографии деасфальтизированной нефти (мальтенов). Предварительно было проведено выделение и определение содержания асфальтеновв образиахнефти. Установлено, чтообработкапластовойнефтизолеобразуютей композичией EOR приводит к изменениям состава компонентов (насыщенных ароматических углеводородов, смол и асфальтенов) и агрегаџионной устойчивости добываемой нефти. Полученные результаты показали, что агрегационная устойчивость тяжелой нефти зависит не только от содержания насыщенных, ароматических углеводородов, смол и асфальтенов в дисперсионной среде. Дополнительным фактором стабилизачии нефтяной дисперсной системы является наличие металлопорфиринов в нефти, которые могут действовать как ингибиторы осаждения асфальтенов.
\end{abstract}

Ключевые слова: методы увеличения нефтеотдачи, золеобразующая композиция, вытеснение, тяжелая нефть, состав, асфальтены, смоль, углеводороды, металлопорфирины, устойчивость, спектрофотометрия. 


\section{Introduction}

The oil composition changes during production, transportation, and processing of crude oils $[1,2]$. It is known that heavy oil is a continuously distributed colloid system with dynamic stability [3]. The effects of compositional changes on asphaltene stability have been investigated for different crude oils, fractionated asphaltenes, and resins with hydrocarbons that act either as asphaltene solvents or flocculating agents. A literature review suggests that much attention is now devoted to the study of the stability of oil dispersed systems, since it plays an important role in the processes of extraction, transport, processing, storage and use of hydrocarbon raw materials $[4,5]$. The change in conditions such as reservoir pressure and temperature, as well as its transportation and storage results in unbalance within the system and can cause changes in the stability. Effects of the addition of resins on aggregation and stability of petroleum asphaltenes in hydrocarbon solutions are studied by dynamic light scattering. The average aggregate size was monitored in real time as a function of the concentration of the precipitant (heptane) and resins. It is shown that resins serve as inhibitors for asphaltene aggregation, shifting the onset of aggregation. However, the dependence of the onset on the concentration of resins has a tendency to saturate $[6,7]$. In the structuring of oil dispersed systems the focus is on asphaltenes, which affect the stability of colloidal oil structure. A decrease in the stability of the oil dispersed system during the development of the oil field and the extraction of oil is accompanied by the deposition of asphaltene-resin-paraffin deposits, which result in the colmatation of rocks and contamination of downhole equipment. They also hamper the technological processes of transportation of hydrocarbon raw materials. However, it is important to accelerate the changes in oil stability during deasphalting, deparaffination, crystallization, etc. The colloidal stability of oil systems depends on the composition and content of the dispersed phase and dispersion medium in the oil. To prevent the deposition of asphaltenes, additives of aromatic hydrocarbons, deasphaltisate, resins and special inhibitory substances can be used.

Aromatic hydrocarbons and resins have a positive effect on the resistance of oil to asphaltene deposition [8]. The number of resins should be sufficient to form an adsorption layer on the surface of asphaltenes and stabilize dispersed systems. The presence of a sufficient amount of aromatic hydrocarbons in the dispersion medium has a positive effect on the stability of asphaltenes, since they have a polyaromatic structure. A large number of studies deals with the mechanisms of these processes, since their understanding allows one to reasonably approach to the choice of physicochemical impacts on the reservoir, aimed at enhancing oil recovery. The composition of oils plays an important role in changing the stability of oil in the formation, when partial dissolution of some components in water and enrichment of oil with resin-asphaltene substances (RAS) and newly formed ones due to chemical and biochemical oxidation take place. The application of enhanced oil recovery (EOR) methods can also have an impact on oil characteristics. The chemical reagents used in the course of EOR methods application can have an inhibitory effect on the deposition of asphaltenes in a crude oil. The changes in the composition of the high-viscosity heavy oil from the Usinskoye oil field due to the formation treatment with the oil-displacing composition containing synthetic surfactant were studied in $[9,10]$. The aim of this work was to study changes in the composition and stability of heavy oil from the Usinskoye field during its production using a solforming system used for the enhanced oil recovery (EOR system). The composition of oil samples 
was investigated and optical absorption spectra of asphaltenes isolated from the oil samples were recorded. During asphaltene precipitation these spectra were analyzed in the visible region via electronic spectrophotometry.

\section{Experimental}

Oil samples. Oil samples from well No. 12XX of Permo-Carbon deposit of the Usinskoye oil field (Komi Republic, Russia ) and those before and after injection of the sol-forming EOR system were taken as subjects of investigation.

EOR system. In the Usinskoye oil field, the sol-forming EOR system was injected by the technology developed in the IPC SB RAS. The sol-forming EOR system (S) is based on aluminum chloride and carbamid [11, 12]. The sol-forming EOR-system (S) injected into the reservoir generates a sol (gel) and $\mathrm{CO}_{2}$, which results in a redistribution of filtration flows, a decrease in water cut, and an increase in oil production.

SARA composition analysis. The content of the main SARA components (saturated and aromatic hydrocarbons, resins, asphaltenes) was determined in the oil samples. To separate asphaltenes, the weighed obtained samples were diluted with a 40-fold excess of hexane and left for 24 hours [13]. A precipitate of asphaltene was removed by filtration through a paper filter and then washed with hexane from co-precipitated resins and hydrocarbons (malthenes). Malthenes were separated by chromatography in a Soxhlet apparatus on silica gel. They were successively eluted with hexane in order to desorption saturated and aromatic hydrocarbons (SA-HCs), and with an alcohol: chloroform mixture (7:93) to isolate the resins [14].

GC-MS analysis. The individual and group composition of compounds in malthenes was analyzed by gas chromatography-mass spectrometry (GC-MS) using a Thermo Scientific DFS magnetic-mass spectrometer (Germany). The data of NIST Mass Spectral Library were used to identify compounds: alkanes, naphthenic (Napht HCs) and aromatic (Aromatic HCs) hydrocarbons, heterorganic compounds (HOC). Ionization was carried out by electron impact; ionizing electron energy was $70 \mathrm{eV}$; temperature of the ionization chamber was $+250 \mathrm{C}$; mass spectra were recorded in the range of 50-500 atomic mass unit; spectrum sweep duration was $1 \mathrm{~s}$.

Porphyrins analysis. Metalloporphyrins were analyzed by the method of elution chromatography on aluminum oxide IV degree of activity. The extraction of fractions was carried out sequentially first with carbon tetrachloride and then benzene. The metalloporphyrins were examined with the aid of UV/VIS-spectrophotometer 'UVIKON 943' (KONTRON INSTRUMENTS, Italy), using the adsorption band intensity in the visible region of the spectrum $(550 \mathrm{~nm}$ for nickel porphyrin and 570 $\mathrm{nm}$ for vanadium porphyrin).

Stability. The aggregative stability of oil samples was measured by the method of spectrophotometry using an UVIKON 943 instrument programmed to automatically record the changes in optical density (D) over time [15]. The n-hexane in a precipitation/solvent ratio of 3:1 was added to a solution of crude oil in toluene ( $3 \mathrm{wt} \%$ concentration). The resulted mixture was rapidly mixed and the kinetic curve of the change in optical density over time was recorded. The optical density of the solutions was measured at a wavelength of $650 \mathrm{~nm}$ in a $1 \mathrm{~cm}$ sealed cell for 150 minutes. The optical density of oil solutions was also measured at a wavelength of $500 \mathrm{~nm}$ to calculate the specific coefficient of light absorption $\mathrm{K}_{500}$ $\left(\mathrm{dm}^{3} / \mathrm{g} \cdot \mathrm{cm}\right)$ according to the formula: 


$$
\mathrm{K}_{500}=\mathrm{D}_{500} / \mathrm{C} \cdot 1
$$

where: $\mathrm{D}_{500}$ is the optical density of the oil solution at a wavelength of $500 \mathrm{~nm}$;

- $\mathrm{C}$ is the concentration of the oil solution in toluene, $\mathrm{g} / \mathrm{dm}^{3}$;

-1 is the thickness of the cell, cm;

- $\mathrm{K}_{500}{ }^{1}$ is the specific light absorption coefficient of the initial oil solution in toluene, $\mathrm{dm}^{3} / \mathrm{g} \cdot \mathrm{cm}$;

- $\mathrm{K}_{500}{ }^{2}$ is the specific light absorption coefficient of the oil solution after addition of hexane and deposition of asphaltenes, $\mathrm{dm}^{3} / \mathrm{g} \bullet \mathrm{cm}$;

- and $\mathrm{K}_{500}{ }^{1} / \mathrm{K}_{500}{ }^{2}$ is the ratio of specific indicators of light absorption.

\section{Results and discussion}

In $[6,15]$ was shown that the one of the main factors affecting the colloidal stability of crude oil is the high content of aromatic hydrocarbons and resins. The resistance of oils to asphaltene precipitation depends on the resin content and the steric position of resins relative to asphaltenes. The stabilization of asphaltenes occurs when resins are adsorbed by aromatic 'heads' on the surface of asphaltenes, while the aliphatic part of resins, so-called 'tails', being in the dispersion phase form a stabilization layer. An additional condition is the chemical affinity of the aliphatic part of resins and a dispersion medium [16].

Table 1 shows the component composition of oil sampled from the wells No.12XX before and after treatment with the sol-forming system $\mathrm{S}$. The total content of saturated and aromatic hydrocarbons (SA-HCs) and resin+asphaltene substances (RAS) in the initial oil sampled from the well No. 12XX was, 71.5 and $28.5 \mathrm{wt} \%$, respectively. The resin/asphaltenes (2.8) and RAS/SA-HCs components (0.4) ratios make it possible to evaluate the aggregative stability [17] (Table 1).

Before the treatment, the content of aromatic hydrocarbons in the initial oil samples was $63 \%$ rel., while that of saturated hydrocarbons $33 \%$ rel., where $26 \%$ were naphthenic hydrocarbons and $7 \%-$ alkanes (Fig. 1).

In Figure 2 are shown the curves of the changes in optical density for oil solutions, which make it possible to evaluate the stability to precipitation of asphaltenes in samples from the well No. 12XX before and after injection of the gelling $\mathrm{S}$ composition.

At the initial stage after the addition of $n$-hexane, a structural rearrangement of the system is observed, which consists in the flocculation of asphaltenes. The optical density increases due to an increase in the contribution of growing particles to the absorption of light. The flocculation is

Table 1. Composition of oil samples taken out from the well No. 12XX before and after treatment with the solforming system $\mathrm{S}$

\begin{tabular}{|c|c|c|c|c|c|}
\hline \multirow{2}{*}{$\begin{array}{c}\text { Oil sample. } \\
\text { Sampling date }\end{array}$} & \multicolumn{3}{|c|}{ Content, wt $\%$} & $\begin{array}{c}\text { Resins/ } \\
\text { Asphaltenes } \\
\text { ratio }\end{array}$ & $\begin{array}{c}\text { RAS / } \\
\text { SA-HCs ratio }\end{array}$ \\
\hline Initial oil & 71.5 & Resins & Asphaltenes & 2.8 & 0.4 \\
\hline 1 month later & 68.2 & 23.5 & 8.5 & 2.8 & 0.5 \\
\hline 3 months later & 63.5 & 26.6 & 9.6 & 2.8 & 0.6 \\
\hline 5 months later & 65.9 & 24.3 & 9.8 & 2.5 & 0.5 \\
\hline 11 months later & 75.0 & 18.2 & 6.8 & 2.7 & 0.3 \\
\hline
\end{tabular}


completed, asphaltene particles precipitate, as can be seen from the decrease in the optical density of the solution as a function of time (Fig. 2).

The injection of the sol-forming system $\mathrm{S}$ resulted in a redistribution of the filtration flows within the formation, which promoted the involvement of heavier high-resin oil into the extraction. The one, three and five months later, the content of RAS in the oil composition has increased from 28.5 to $31.8-36.2 \mathrm{wt} \%$, while the resins/asphaltenes ratio remained unchanged. The ratio of RAS to SA-HCs components increased from 0.4 to $0.5-0.6$ (Table 1). The content of aromatic hydrocarbons decreased by $7 \%$ rel., while that of saturated hydrocarbons increased by $2 \%$ rel. In particular, the content in naphthenic HCs increased by $6 \%$ and that in alkanes decreased by $4 \%$ (Fig. 1). It is evident from Fig. 2 (curves 3 and 4) that the oil sampled 3 and 5 months after the injection of the system $\mathrm{S}$ have a higher resistance to asphaltene precipitation. This resulted in an increase in the aggregative oil stability.

Eleven months after treatment, the ratio of resin-asphaltene components to hydrocarbons (RAS / SA-HCs) decreased to 0.3 (Table 1). The content of aromatic hydrocarbons decreased by $15 \%$ rel.,

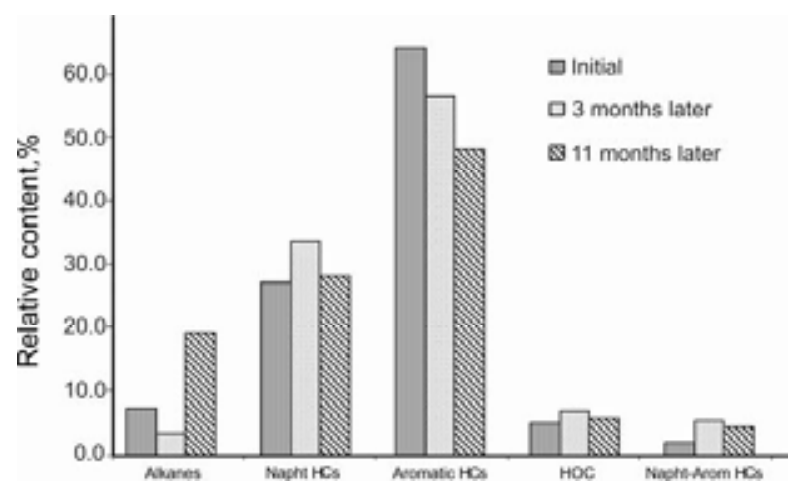

Fig. 1. Group composition of the saturated and aromatic hydrocarbons for oil samples from the well No. 12XX, sampled at various time periods (before and after treatment with the sol-forming system S)

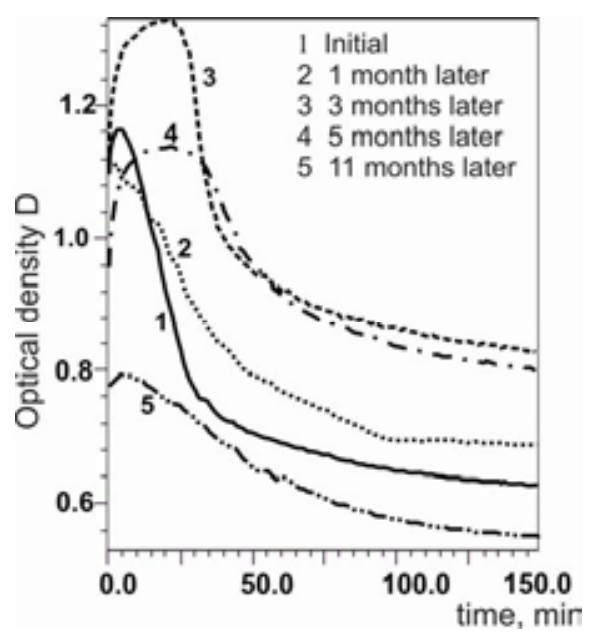

Fig. 2. Changes in the optical density of the solution during asphaltene precipitation from oil samples: well No. $12 X X$ (the sol-forming system $\mathrm{S}$ ) 
while the content of saturated hydrocarbons increased by $12 \%$ rel. as compared to the initial oil sample. In particular, the content in naphthenic HCs increased by $1 \%$ and that in alkanes by $11 \%$ (Fig. 1). The combination of these indicators affected the stability of the oil. Hence, the oil sample exhibited the lowest optical density, and thus, the lowest stability (Fig. 2, curve 5).

This confirms the dependence of the oil stability on the content of natural stabilizers represented by resins. It was found out in [15] that the ratio of the specific light absorption coefficient of the initial oil solution $\left(\mathrm{K}_{500}{ }^{1}\right)$ to that of the solution after asphaltene precipitation $\left(\mathrm{K}_{500}{ }^{2}\right)$ correlates well with the resins/asphaltenes ratio. So, the higher the fraction of resins and lower the value of $K_{500}{ }^{1} / K_{500}{ }^{2}$, the higher is oil stability.

Based on the spectral data in the UV visible region of spectrum the ratios of specific light absorption coefficients $\left(\mathrm{K}_{500}{ }^{1} / \mathrm{K}_{500}{ }^{2}\right)$ for the oil samples from the Usinskoye oil field were calculated. Oil samples from the well No. 12XX sampled 3 and 5 months later after treatment are characterized by the minimum $\mathrm{K}_{500}{ }^{1} / \mathrm{K}_{500}{ }^{2}$ ratio, 1.45 and 1.48 , respectively, which indicates its higher stability.

It was shown in [18] that the introduction of a concentrate of vanadylporphyrins into the model mixture results in an increase in the aggregative stability of the system obtained. It is known that one of the important factors affecting the stability of oil is the nature of the asphaltenes themselves. Oil vanadylporphyrins are close in size and molecular weight to the structures of the light fraction of asphaltenes, so they act as dispersants, preventing agglomeration of asphaltene nanoaggregates and formation of flocculi [19]. Vanadylporphyrins inhibit the asphaltene precipitation due to multiple intermolecular interactions. Hence, the addition of the concentrate of vanadylporphyrins to oil resins increases their effectiveness as asphaltene precipitation inhibitors, which is of practical importance. It has been shown that with an increase in the content of vanadilporphyrins in the resins of heavy oils, their ability to precipitate asphaltenes decreases. The addition of the concentrate of vanadylporphyrins to petroleum resins increases their effectiveness as an inhibitor of asphaltene precipitation, which has practical prospects in technological processes of production of extra-viscous oil using hydrocarbon solvents based on light alkanes.

Metalloporphyrins have been identified in the oil samples from the Usinskoye oil field. They contain large concentrations $(170-310 \mathrm{nmol} / \mathrm{g})$ of vanadyl complexes [20]. Comparison of data on stability with those on the content of metal complexes in oil samples showed a relationship between these parameters. Hence, a decrease in the content of porphyrins is proportional to a decrease in aggregative stability $\left(\mathrm{K}_{500}{ }^{1} / \mathrm{K}_{500}{ }^{2}\right)$ of oil sampled 1 month after treatment with the sol-forming system S (see Fig. 3). Thus, a study of the samples of heavy high-viscosity oil from the Usinskoye oil field has been shown that in the case of field application the aggregative stability of oils increases with increasing content in metalloporphyrins.

Over time ( 3 and 5 months after the injection of the system $\mathrm{S}$ ) the content of metalloporphyrins in the samples increased by 1.3 -1.8 times. The stability of the oil was observed also increased.

\section{Conclusions}

The results obtained showed that the aggregative stability of crude oil is affected not only by the content of aromatic hydrocarbons and resins in the dispersion medium. An additional factor in stabilizing the oil dispersed system is the presence of metalloporphyrins in the oil, which can act as inhibitors of asphaltene precipitation. The ratio of the specific light absorption coefficient of the 


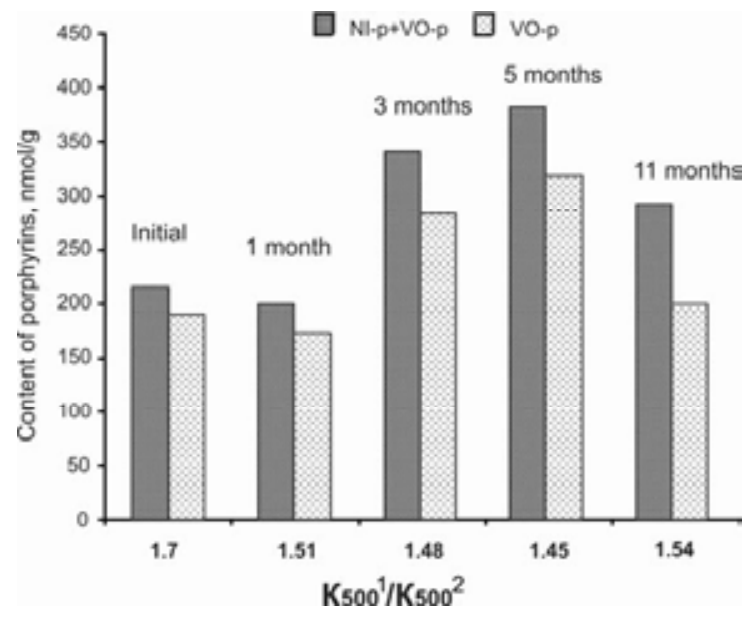

Fig. 3. Dependence of the content of porphyrins and the stability $\left(K_{500}{ }^{1} / K_{500}^{2}\right.$ ratio) for oil samples from the well No. 12XX, sampled at various time periods (before and after treatment with the sol-forming system $\mathrm{S}$ )

initial oil solution $\left(\mathrm{K}_{500}{ }^{1}\right)$ to that of the solution after asphaltene precipitation $\left(\mathrm{K}_{500}{ }^{2}\right)$ makes it possible to rapidly evaluate the oil stability. The selection of the necessary minimum high-performance additives of asphaltene precipitation inhibitors optimizes the processes of super-viscous heavy oil production.

\section{Acknowledgements}

The authors are grateful to the researchers of the Laboratory of Colloidal Oil Chemistry of the Institute of Petroleum Chemistry SB RAS for selection and provision of the oil samples.

The work was performed within the framework of project V.46.2.3. Physical chemistry and rheology of oil and polydisperse oil-containing systems in the processes of Enhanced Oil Recovery and oil transportation (No. AAAA-A17-117030310202-8).

\section{References}

1. Santos R.G., Loh W., Bannwart A.C., Trevisan O.V. An overview of heavy oil properties and its recovery and transportation methods. Brazilian Journal of Chemical Engineering 2014. Vol. 31 (3), P. 571-590.

2. Martinez-Paloua R., Mosquirra M. L., Zapata-Rendonb B. et al. Transportation of heavy and extra heavy crude oil by pipeline: A review. Journal of Petroleum Science and Engineering 2011. Vol. $75(3-4)$, P. 274-282.

3. Kayukova G.P., Petrov S.M., Romanov G.V. and Sakhibgareev I.R. Features of the heavy oil composition change during Mordovo-Karmalskoye field operation. Oil industry 2012. No 1, P. $78-81$. (In Russ.)

4. Guo K., Li H., Yu Z. In-situ heavy and extra heavy oil recovery: A review. Fuel 2016. No 185, P. $886-902$.

5. Pereira J. C., Lopez I., Salas R., Silva F. et al. Resins: The molecules responsible for the stability/ instability phenomena of asphaltenes. Energy Fuels 2007. Vol. 21 (3), P. 1317-1321. 
6. Anisimov M. A., Ganeeva Yu. M. et al. Effects of Resins on Aggregation and Stability of Asphaltenes. Energy Fuels 2014. Vol. 28 (10). P. 6200 - 6209.

7. Buenrostro-GonzalezE., Espinosa-Pena M., Andersen S. I., and Lira-Galeana C. Characterization of asphaltenes and resins from problematic Mexican crude oils. Petroleum Science and Technology 2001. Vol. 19 (3), P. 299 - 316.

8. Wang J. and Buckley J.S. Asphaltene Stability in Crude Oil and Aromatic Solvents The Influence of Oil Composition. Energy Fuels 2003. Vol. 17 (6), P. 1445 - 1451. DOI: 10.1021/ ef030030y.

9. Sherstyuk S.N., Serebrennikova O.V., Stakhina L.D., Kadichagov P.B. The effect of EOR technologies on the composition of recovered crude oil. J. Siberian Federal University. Chemistry 2010. Vol. 3(2), P. 110 - 119. (In Russ.)

10. Savinykh Yu. V., Chuikina D. I. Dynamics of changes in oil composition at the development of the Usinsk deposit. Proceedings of the International Conference on Advanced Materials with Hierarchical Structure for New Technologies and Reliable Structures, AIP Conference Proceeding. 2016 P.1783. http://dx.doi.org/10.1063/1.4966493

11. Altunina L. K., Kuvshinov V. A. Improved oil recovery of high-viscosity oil pools with physicochemical methods at thermal-steam treatments. Oil \& Gas Science and Technology 2008. Vol. 63(1), P. $37-48$.

12. Altunina L.K., Kuvshinov V.A., Kuvshinov I.V. Gels, Sols and Surfactant Compounds Applied for Enhanced Oil Recovery at the Late Stage of Development. Georsources 2014. No 4, P. 20-27. (In Russ.)

13. GOST 11858-66. Petroleum and its products. Method for determination of asphaltic resinous substance content. Moscow (Russian Federation): IPK Publishing House of Standards. 1977 - 11p. 14. Fomin G.S., Fomina O.N. Oil and petroleum products. Encyclopedia of international standards. Moscow. 2006. 1040 p. (In Russ.)

15. Petrenko T.V., Chuikina D.I., and Stakhina L.D. Use of the Technique of Spectrophotometry to Study the Stability of Crude Oil from the Usinsk Field. Chemistry for Sustainable Development 2018. Vol. 26 (1), P. 37 - 41. DOI: 10.15372/KhUR20180107. (In Russ.)

16. Petrova T.V., Abbakumova N.A., Romanov G.A. Structure and mobility of components of petroleum disperse systems. Doklad Chemistry 2008. Vol. 423(1), P. 283-285. (In Russ.)

17. Alcázar-Vara L. A., Zamudio-Rivera L.S., Buenrostro-González E. Effect of Asphaltenes and Resins on Asphaltene Aggregation Inhibition, Rheological Behaviour and Waterflood Oil-Recovery. Journal of Dispersion Science and Technology 2016. Vol. 37(11), P. 1544-1554.

18. Milordov D.V., Kosachev I.P., Sinyashin K.O. et al. Content and types of vanadyl porphyrins in asphaltenes and resins of heavy oils from various productive complexes. $17^{\text {th }}$ International Multidisciplinary Scientific Geoconference Proceeding. SGEM 2017, Albena, Bulgary. 2017. 29 June -05 July, P. $109-116$.

19. Milordov D.V. Composition and properties of porphyrins of heavy oils and oil residues with a high content of vanadium and nickel. Ph.D. thesis, A.E. Arbuzov Institute of Organic and Physical Chemistry, Kazan Scientific Center, Russian Academy of Sciences, 2016. 24 p. (In Russ.)

20. Stakhina L.D, Petrenko D.S. and Spabekova A.S. The Effect of EOR Technologies on the Content of Petroporphyrins and Naphthenic Acids of Recovered Heavy Oils From Usinskoye Field. Key Engineering Materials 2016. 670. P. 39 - 45. DOI:10.4028/www.scientific.net/KEM.670.39. 